PATIK : Jurnal Hukum

https://ejournal.uhn.ac.id/index.php/patik

Volume 09 Nomor 01 April 2020 Page : 29 - 39

p-issn : 2086 - 4434

\title{
PERTANGGUNG JAWABAN PIDANA PELAKU YANG MENYALAHGUNAKAN NARKOTIKA GOLONGAN I (BUKAN TANAMAN) YANG BERATNYA MELEBIHI 5 GRAM
}

\author{
Theo Fazar Siallagan, Jinner Sidauruk, Tulus Siambaton \\ Fakultas Hukum, Universitas HKBP Nommensen \\ jinnersidauruk@uhn.ac.id
}

\begin{abstract}
Abstrak
Bahaya dan akibat dari penyalahgunaan narkotika tgersebut dapat bersifat bahaya pribadi bagi sipemakai dan dapat pula berupa bahaya sosial masyarakat atau lingkungan, maka yang menjadi rumusan masalah adalah untuk mengetahui bagaimana pertanggungjawaban pelaku pidana yang menyalah gunakan narkotika golongan I (Bukan tanaman) yang beratnya melebihi 5 gram (Studi Putusan No.2638/Pid.Sus/2019/Pn.Medan). Jenis penelitian yang digunakan dalam penelitian ini adalah yuridis normatif yaitu suatu penelitian hukum yang dilakukan dengan cara meneliti dan menelaah pustaka atau data sekunder. banyaknya keselahan yang dalam bentuk kelaaliann maupun kesengaajaan, dimulai dari jenis dakwaan yang digunakan, yang seharusnya menggunakan dakwaan subsideir akan tetapi jaksa penuntut umum memilih dakwaan alternatif, sesuai dengan fakta hukum yang ada, sangat jelas terbukti pasal 114 pada dakwaan alternatif pertama terbukti sesuai dengan BAP, akan tetapi hakim berpendapat lain sehingga memutuskan untuk memilih dakwaan alternatif kedua. Seharusnya penegak hukum harus sesuai dengan asas "Fiat justitia ruat caelum" artinya "Hendaklah keadilan ditegakkan, walaupun langit akan runtuh.
\end{abstract}

Kata Kunci: Dakwaan, Narkotika, Pertanggungjawaban pidana, Penegakan hukum pidana

\begin{abstract}
The dangers and consequences of the abuse of narcotics can be personal hazards to the user and can also be in the form of social or environmental hazards, so the problem formulation is to find out how the accountability of criminals who abuse narcotics class I (not plants) weighing more than 5 grams. (Decision Study No.2638 / Pid.Sus / 2019 / Pn.Medan). The type of research used in this research is juridical normative, namely a legal research conducted by researching and reviewing literature or secondary data. The number of mistakes in the form of negligence or deliberate action, starting with the type of indictment used, which should have used the subside indictment, but the public prosecutor chose alternative charges, in accordance with the existing legal facts, it is very clear that article 114 of the first alternative indictment is proven in accordance with the BAP However, the judge had a different opinion and decided to choose the second alternative indictment. Law enforcers should comply with the principle of "Fiat justitia ruat caelum" which means "Justice be upheld, even though the sky will collapse.
\end{abstract}

Keywords: Indictment, Narcotics, Criminal Liability, Criminal Law Enforcement, 
PATIK : JURNAL HUKUM Vol : 09 No. 1, April 2020, Hal 29 - 39

\section{Pendahuluan}

Setiap Masyarakat dalam hidupnya pasti pernah mengalami perubahan-perubahan, ada yang tidak menarik perhatian orang, ada yang pengaruhnya luas, ada yang terjadi sangat lambat dan juga yang terjadi sangat cepat, adapula yang direncanalan dan seterusnya. perrubahan itu bisa berdampak positif ada pula yang berdampak negatif. Perubahan yang berdampak positif contohnya yaitu cepatnya perkembangan dibidang teghnologi yang sudah kita rasakan saat ini, dan dampak negatifnya salah satunya adalah masuknya barang-barang haram yang dikategorikan sebagai Narkotika dan penyebaranya sangat pesat di Indonesia. Disini Hukum hadir Sebagai alat untuk mengubah masyarakat atau untuk mengkontrol perubahan itu, hukum hadir sebagai penyeimbang ${ }^{1}$

Dalam hukum Indonesia kejahatan Narkotika dan Psikotrapika, merupakan kejahatan kemanusiaan yang berat, yang mempunyai dampak luar biasa, terutama pada generasi muda suatu bangsa yang beradab. Kejahatan narkotika merupakan kejahatan lintas negara, karena penyebaran dan perdagangan gelapnya, dilakukan dalam lintas batas negara. Dalam kaitannya dengan negara Indonesia sebagai negara hukum ialah negara yang menegakkan supremasi hukum untuk menegakkan kebenaran dan keadilan. Secara umum, dalam setiap negara yang menganut paham negara hukum terdapat tiga prinsip dasar, yaitu supremasi hukum (supremacy of law), kesetaraan dihadapan hukum (equality before the law), dan penegakan hukum dengan cara yang tidak bertentangan dengan hukum (due process of law). Pertanggungjawaban pidana terkait penyalahgunaan produk turunan narkotika sangat diperlukan dalam penegakan hukum pidana di Indonesia hal ini dikarenakan produk turunan narkotika memiliki efek yang sangat buruk bagi kesehatan manusia yaitu dapat merusak fisik dan mental. Bahaya dan akibat dari penyalahgunaan narkotika tgersebut dapat bersifat bahaya pribadi bagi sipemakai dan dapat pula berupa bahaya sosial masyarakat atau lingkungan ${ }^{2}$.

Produk turunan narkotika masih belum diatur secara spesifik oleh Undang-Undang Nomor 35 Tahun 2009 Tentang Narkotika. Sehingga, pertanggungjawabannya terbentur oleh asas legalitas, "nullum delictum, nulla poena sine praevia lege poenali"3 Suatu tindak pidana tidak dapat dipertanggungjawabkan dalam hukum pidana apabila tidak terdapat peraturan yang mengaturnya terlebih dahulu. Atau dengan kata lain. Hal ini juga sesuai dengan aliran Hukum Positif, yang mana mengidentikkan hukum dengan undangundang, atau dengan kata lain tidak ada hukum diluar undang-undang ${ }^{4}$ maka, dalam hal ini dapat menjadi celah hukum bagi pelaku tindak pidana penyalahgunaan produk turunan narkotika. Selanjutnya diperlukan upaya pemerintah dan instansi terkait untuk membentuk pertanggungjawaban pidana bagi pelaku tindak pidana penyalahgunaan produk turunan narkotika serta bagaimana seharusnya undang-undang mengatur mengenai produk turunan narkotika, Sehingga pelaku tindak pidana tidak lepas dari jeratan hukum.

Ketentuan perundang-undangan yang mengatur masalah narkotika telah disusun dan diberlakukan, namun demikian kejahatan yang menyangkut tentang narkotika belum dapat diredakan. Dalam banyak kasus terakhir, banyak bandar-bandar dan pengedar yang tertangkap dan mendapat sanksi berat, namun pelaku lain seperti tidak mengacuhkannya bahkan lebih cenderung untuk memperluas daerah operasinya. Kejahatan narkotika dan

${ }^{1}$ Soerjono Soekanto, "Pokok-Pokok Sosilologi Hukum” Raja Grafindo Persada,cetakan ke-12, Jakarta 2002, hlm 16

2 Moh, Taufik Makarro, Suhasril, H.Moh.Zakky "tindak Pidana Narkotika" Ghalia Indonesia" Jakarta 2003 hlm 49

3 "Bambang Poeromo" "Asaas-asas Hukum Pidana" Ghalia Indonesia terbitan ke-7 Yogyakarta 1994, Hlm 68

${ }^{4}$ H. Lili rasjidi dan Ira Thania Rasjidi “ Dasar-Dasar Filsafat dan Teori Hukum” Citra Aditya Bakti, cetkan ke-11, Bandung 2004, hlm 56 


\section{PATIK : JURNAL HUKUM Vol : 09 No. 1, April 2020, Hal 29 - 39}

obat-obatan terlarang pada masa sekarang telah bersifat transnasional yang dilakukan dengan modus operandi yang tinggi dan teknologi yang canggih, aparat penegak hukum diharapkan mampu mencegah dan menanggulangi kejahatan tersebut guna meningkatkan moralitas dan kualitas sumber daya manusia di Indonesia, khususnya bagi generasi penerus bangsa. Kejahatan narkotika masih menjadi masalah kronis yang menimpa Indonesia. Berbagai cara telah dilakukan oleh pemerintah untuk memberantas kejahatan yang telah merenggut banyak nyawa anak bangsa ini. Salah satunya di bidang regulasi yang ditandai dengan diundangkannya Undang-Undang Nomor 22 Tahun 1997 tentang Narkotika. Seiring dengan perkembangan kejahatan narkotika, undang-undang tersebut dianggap sudah tidak lagi memadai, maka kemudian dikeluarkan Undang-Undang Nomor 35 tahun 2009 tentang Narkotika. Berdasarkan uraian diatas, maka yang menjadi rumusan masalah adalah untuk mengetahui bagaimana pertanggungjawaban pelaku pidana yang menyalah gunakan narkotika golongan I (Bukan tanaman) yang beratnya melebihi 5 gram (Studi Putusan No.2638/Pid.Sus/2019/Pn.Medan).

\section{Tinjauan Pustaka}

Sistem pertanggungjawaban pidana dalam hukum pidana positif saat ini menganut asas kesalahan sebagai salah satu asas disamping asas legalitas. Asas kesalahan yaitu tiada pidana tanpa kesalahan. Walaupun asas ini tidak secara tegas tercantum dalam KUHP maupun peraturan lainnya, namun berlakunya asas tersebut sudah tidak diragukan lagi. Jadi Pertanggungjawaban pidana yaitu menyangkut pada diri "Orang atau Pelaku".Pertanggungjawaban pidana menjurus kepada pemidanaan pelaku, jika melakukan suatu tindak pidana dan memenuhi unsur-unsur yang telah ditentukan oleh undang-undang.

Dilihat dari terjadinya perbuatan yang terlarang, ia akan diminta pertanggungjawaban apabila perbutan tersebut melanggar hukum. Dilihat dari sudut kemampuan bertanggungjawab makahanya orang yang mampu bertanggungjawab yang dapat diminta pertanggungjawaban. Pertanggungjawaban pidanadalam istilah asing tersebut juga dengan teorekenbaardheid atau criminal responsibility yang menjurus kepada pemidanaan petindak dengan maksud untuk menentukan apakah seseorang terdakwa atau tersangka dipertanggung jawabkan atas suatu tindakan pidana yang terjadi atau tidak. Pertanggungjawaban pidana dapat dihubungkan dengan fungsi preventif hukum pidana. ${ }^{5}$

Pemidanaan bisa diartikan sebagai tahap penetapan sanksi dan juga tahap pemberian sanksi dalam hukum pidana. Kata "pidana" pada umumnya diartikan sebagai hukum, sedangkan "pemidanaan" diartikan sebagai penghukuman. Doktrin membedakan hukum pidana materil dan hukum pidana formil. J.M. Van Bemmelen menjelaskan kedua hal tersebut sebagai berikut $:^{6}$ Hukum pidana materil terdiri atas tindak pidana yang disebut berturut- turut, peraturan umum yang dapat diterapkan terhadap perbuatan itu, dan pidana yang diancamkan terhadap perbuatan itu. Hukum pidana formil mengatur cara bagaimana acara pidana seharusnya dilakukan dan menentukan tata tertib yang harus diperhatikan pada kesempatan itu. Di Indonesia sendiri, hukum positif belum pernah merumuskan tujuan pemidanaan. Selama ini wacana tentang tujuan pemidanaan tersebut masih dalam tataran yang bersifat teoritis. Namun sebagai bahan kajian, Rancangan KUHP Nasional telah menetapkan tujuan pemidanaan pada Buku Kesatu Ketentuan Umum dala Bab II

\footnotetext{
${ }^{5}$ Choerul Huda, Dari Tiada Pidana Tanpa Kesalahan Menuju Kepada Tiada Pertanggungjawaban Pidana tanpa Kesalahan, Kencana, Jakarta, 2006, hlm. 62

${ }^{6}$ Leden Marpaung, Asas-Teori-Praktik Hukum Pidana, Sinar Grafika,. Jakarta, 2005, hlm. 2.
} 


\section{PATIK : JURNAL HUKUM Vol : 09 No. 1, April 2020, Hal 29 - 39}

dengan judul Pemidanaan, Pidana dan Tindakan. Tujuan pemidanaan menurut Wirjono Prodjodikoro, yaitu: ${ }^{7}$

1. Untuk menakut-nakuti orang jangan sampai melakukan kejahatan baik secara menakut-nakuti orang banyak (generals preventif) maupun menakutnakuti orang tertentu yang sudah melakukan kejahatan agar dikemudian hari tidak melakukan kejahatan lagi (speciale preventif), atau

2. Untuk mendidik atau memperbaiki orang-orang yang melakukan kejahatan agar menjadi orang-orang yang baik tabiatnya sehingga bermanfaat bagi masyarakat.

Pengertian Narkotika berdasarkan ketentuan Pasal 1 angka 1 Undang-undang Nomor 35 tahun 2009 tentang Narkotika, bahwa yang dimaksud dengan Narkotika adalah zat atau obat yang berasal dari tanaman atau bukan tanaman, baik sintetis maupun semisintetis, yang dapat menyebabkan penurunan atau perubahan kesadaran, hilangnya rasa, mengurangi sampai menghilangkan rasa nyeri, dan dapat menimbulkan ketergantungan. Narkotika yang terkenal di Indonesia sekarang ini berasal dari kata "Narkoties", yang sama artinya dengan kata narcosis yang berarti membius. Dulu di Indonesia dikenal dengan sebutan madat.

Dalam penjelasan Umum Undang-undang Nomor 35 tahun 2009 tentang Narkotika mempunyai cakupan yang lebih luas baik dari segi norma, ruang lingkup materi maupun ancaman pidana yang diperberat. Cakupan yang lebih luastersebut selain didasarkan pada faktor-faktor diatas juga karena perkembangan kebutuhan dan kenyataan bahwa nilai dan norma dalam ketentuan yang berlaku tidak memadai lagi sebagai sarana efektif untuk mencegah dan memberantas penyalahgunaan dan peredaran gelap narkotika. Salah satu materi baru dalam Undang-undang Nomor 35 tahun 2009 tentang Narkotika, dibagi menjadi 3 (tiga) golongan, mengenai bagaimana penggolongan dimaksud dari masingmasing golongan telah di rumuskan dalam Pasal 6 ayat (1) Undang-undang Narkotika.

Tindak Pidana Narkotika diatur dalam Bab XV Pasal 111 sampai dengan Pasal 148 Undang-undang Nomor 35 tahun 2009 yang merupakan ketentuan khusus, walaupun tidak disebutkan dengan tegas dalam Undang-undang Narkotika bahwa tindak pidana yang diatur di dalamnya adalah tindak kejahatan, akan tetapi tidak perlu disangksikan lagi bahwa semua tindak pidana di dalam undang-undang tersebut merupakan kejahatan. Alasannya, kalau narkotika hanya untuk pengobatan dan kepentingan ilmu pengetahuan, maka apabila ada perbuatan diluar kepentingan-kepentingan tersebut sudah merupakan kejahatan mengingat besarnya akibat yang ditimbulkan dari pemakaian narkotika secara tidak sah sangat membahayakan bagi jiwa manusia. ${ }^{8}$ Penggunaan narkotika secara legal hanya bagi kepetingan- kepentingan pengobatan atau tujuan ilmu pengetahuan. Menteri Kesehatan dapat memberi ijin lembaga ilmu pengetahuan dan atau lembaga pendidikan untuk membeli atau menanam, menyimpan untuk memiliki atau untuk persediaan ataupun menguasai tanaman papaver, koka dan ganja. ${ }^{9}$

Penanggulangan terhadap tindak pidana narkotika dapat dilakukan dengan cara preventif, moralistik, abolisionistik dan juga kerjasama internasional. Penanggulangan secara preventif maksudnya usaha sebelum terjadinya tindak pidana narkotika, misalnya dalam keluarga, orang tua, sekolah, guru dengan memberikan penjelasan tentang bahaya narkotika. Selain itu juga dapat dengan cara mengobati korban, mengasingkan korban

${ }^{7}$ Wirjono Prodjodikoro, Hukum Acara Pidana di Indonesia, Sumur Bandung, Bandung, 1981, hlm.

${ }^{8}$ Supramono, G. 2001. Hukum Narkotika Indonesia.Djambatan, Jakarta.

${ }^{9}$ Soedjono Dirjosisworo.1990. Hukum Narkotika di Indonesia. Bandung citra Aditya bakti. 
narkotika dalam masa pengobatan dan mengadakan pengawasan terhadap bekas pecandu narkotika.

\section{Metode}

Jenis penelitian hukum ini termasuk penelitian yuridis normatif yaitu penelitian yang berdasarkan pada bahan kepustakaan yang ada. Penelitian ini dengan pendekatan studi kasus yang meliputi ketentuan perundang-undangan dan putusan pengadilan serta literatur-literatur yang berhubungan dengan pokok bahasan. Bahan Hukum yang dilakukan dalam penelitian ini adalah secara kualitatif yaitu penelitian yang mengacu pada norma hukum yang terdapat dalam peraturan perundang-undangan dan analisis terhada putusan Nomor 2638/Pid.Sus/2019/ Pn. Medan yaitu tentang Pertanggung jawaban Pidana pelaku yang menyalahgunakan Narkotika Golongan 1 (Bukan Tanaman) yang beratnya melebihi 5 gram

\section{Pembahasan Dan Hasil}

Sebagaimana Dakwaan yang ditetapkan oleh jaksa penuntut umum dalam putusan ini adalah menggunakan dakwaan alternatif, dimana pengertian dari dakwaan alternatif adalah dakwaan pilihan, atau dengan kata lain cukup salah satu dakwaan saja yang harus dibuktikan untuk menuntut terdakwa, dakwaan alternatif dapat dilihat dengan kata "atau" Dakwaan adalah salah satu Kewenangan yang diberikan kepada peraturan perundangundangan kepada kejaksaan untuk melakukan penuntutan kepada terdakwa suatu tindak pidana. Dimana diajukanya dakwan itu adalah berdasarkan BAP (Berita Acara Penyidikan) yang di ajukan penyidik, dalam hal ini yaitu kepolisian. Dalam hal dakwaan, pada umumnya berisi pasal yang didakwakan atau diyakini telah dilanggar oleh terdakwa pada perbuatanya sehingga harus di adili. Dalam sistem peradilan Indonesia dikenal beberapa jenis dakwaan diantanya :

1. Dakwaan Tunggal

Dalam surat dakwaan ini hanya satu Tindak Pidana saja yang didakwakan, karena tidak terdapat kemungkinan untuk mengajukan alternatif atau dakwaan pengganti lainnya;

2. Dakwaan Alternatif

Dalam surat dakwaan ini terdapat beberapa dakwaan yang disusun secara berlapis, lapisan yang satu merupakan alternatif dan bersifat mengecualikan dakwaan pada lapisan lainnya. Bentuk dakwaan ini digunakan bila belum didapat kepastian tentang Tindak Pidana mana yang paling tepat dapat dibuktikan. Dalam dakwaan alternatif, meskipun dakwaan terdiri dari beberapa lapisan, hanya satu dakwaan saja yang dibuktikan tanpa harus memperhatikan urutannya dan jika salah satu telah terbukti maka dakwaan pada lapisan lainnya tidak perlu dibuktikan lagi.

3. Dakwaan Subsidair

Sama halnya dengan dakwaan alternatif, dakwaan subsidair juga terdiri dari beberapa lapisan dakwaan yang disusun secara berlapis dengan maksud lapisan yang satu berfungsi sebagai pengganti lapisan sebelumnya. Sistematik lapisan disusun secara berurut dimulai dari Tindak Pidana yang diancam dengan pidana tertinggi sampai dengan Tindak Pidana yang diancam dengan pidana terendah.

4. Dakwaan Kumulatif 


\section{PATIK : JURNAL HUKUM Vol : 09 No. 1, April 2020, Hal 29 - 39}

5. Dalam Surat Dakwaan ini, didakwakan beberapa Tindak Pidana sekaligus, ke semua dakwaan harus dibuktikan satu demi satu. Dakwaan yang tidak terbukti harus dinyatakan secara tegas dan dituntut pembebasan dari dakwaan tersebut. Dakwaan ini dipergunakan dalam hal Terdakwa melakukan beberapa Tindak Pidana yang masing-masing merupakan Tindak Pidana yang berdiri sendiri.Contoh dakwaan kumulatif:

5. Dakwaan Kombinasi

Disebut dakwaan kombinasi, karena di dalam bentuk ini dikombinasikan atau digabungkan antara dakwaan kumulatif dengan dakwaan alternatif atau subsidair.

6. Kesimpulan dakwaan

Sehubungan dengan pasal yang didakwakan pada dakwaan alternatife diatas penulis berpendapat adanya tingkatan pidana pada ayat atau tuntutan hukuman pada pasal pidananya tidak setingkat atau dengan kata lain dakwaan yang diajukan oleh jaksa penuntut umum seharusnya tidak menggunakan dakwaan alternatife atau dengakn kata lain "pilihan" melainkan menggunkan dakwaan subsidair yaitu dakwaan yang mana pasal yang paling tinggi harus dibuktikan terlebih dahulu yaitu pasal 144 uu narkotika. Hingga pasal yang tuntutan hukumnya lebih rendah

Tuntutan adalah apa yang dimintakan jaksa pada dakwaanya kepada hakim untuk dimuat kedalam putusanya, pada tuntutan diatas sebagaimana yang dibacakan oleh jaksa penuntut umum jaksa menuntut : "Menyatakan terdakwa BUDI VANDO SINAGA terbukti secara sah danmeyakinkan bersalah melakukan tindak pidana "percobaan ataupermufakatan jahat untuk melakukan tindak pidana tanpa hak danmelawan hukum memiliki, menyimpan, menguasai, atau menyediakanNarkotika Golongan-I bukan tanaman yang beratnya lebih dari 5 (lima)gram" melanggar Pasal 112 ayat (2) jo pasal 132 (1) UU RI No.35 tahun 2009 Tentang Narkotika dalam Dakwaan pertama;"

Setelah penulis membaca dakwaan yang diajukan jaksa penuntut umum, ternyata pada tuntutanya jaksa penuntut umum memintatakan isi daridakwaan kedua, dengan kata lain adanya ketidak sesuaian dengan apa yang dimintakan, penulis berpendapat adanya kelalaian pada jaksa pada pembuatan dakwaan, atau hakim tidak serius menanggapi apa yang dimintakan oleh jaksa penuntut umum.

Hakim dalam menentukan terwujudnya nilai dari suatu putusan harus memberikan keadilan (ex aequo et bono) dan mengandung kepastian hukum,di samping itu juga mengandung manfaat bagi para pihak yang bersangkutan sehingga sebuah pertimbangan yang dilakukan oleh Hakim tersebut harus disikapi dengan teliti, baik, dan cermat. Hakim dalam pemeriksaan suatu perkara juga membutuhkan adanya pembuktian,dimana hasil dari pembuktian itu akan digunakan sebagai bahan pertimbangan dalam memutus perkara. Pembuktian merupakan tahap yang paling penting dalam pemeriksaan di persidangan. Pembuktian bertujuan untuk memperoleh kepastian bahwa suatu peristiwa atau fakta yang diajukan itu benar-benar terjadi, guna mendapatkan putusan Hakim yang benar dan adil. Hakim tidak dapat menjatuhkan suatu putusan sebelum nyata baginya bahwa peristiwa atau fakta hukum tersebut benar-benar terjadi, yakni dibuktikan kebenaranya, sehingga nampak adanya hubungan hukumantara para pihak.

Menimbang, bahwa Terdakwa telah didakwa oleh Penuntut Umum dengan dakwaan yang berbentuk alternatif, sehingga Majelis Hakim dengan memperhatikan fakta-fakta hukum tersebut diatas memilih langsung dakwaan alternatif kedua sebagaimana diatur dalam Pasal 112 Ayat (2) Jo Pasal 132Ayat (1) 


\section{PATIK : JURNAL HUKUM Vol : 09 No. 1, April 2020, Hal 29 - 39}

UU RI No. 35 Tahun 2009 tentang Narkotika, yang unsur-unsurnyaadalah sebagai berikut :

1. Setiap Orang.

2. Percobaan atau permufakatan jahat untuk melakukan tindak pidana tanpa hak dan melawan hukum memiliki, menyimpan, menguasai, atau menyediakan Narkotika Golongan I bukan tanaman yang beratnya lebih dari 5 (lima) gram.

Ad.1. Setiap Orang.

Menimbang bahwa kata "setiap orang" menunjukkan kepada siapaorangnya harus bertanggungjawab atas perbuatan/ kejadian yang didakwakanatau siapa orang yang harus dijadikan terdakwa;

Menimbang, bahwa unsur ini menunjuk pada subyek hukum yangmelakukan perbuatan pidana dan dapat mempertanggung jawabkan perbuatannya ; Menimbang, bahwa dari fakta-fakta yang terungkap di persidangan yaitu keterangan saksi-saksi, keterangan terdakwa, surat, petunjuk dan dikuatkan dengan barang bukti bahwa pelaku tindak pidana dalam perkara ini adalahterdakwa yang di depan persidangan mengaku bernama Budi Vando Sinaga.

Menimbang, bahwa terhadap terdakwa yang telah diajukan dalam persidangan ini karena melakukan tindak pidana dan terdakwa selama persidangan dapat menjawab segala pertanyaan dengan baik serta cakap bertindak dalam hukum dan dapat dimintai pertanggung jawaban secara hokum atas perbuatannya dan tidak ada ditemukan unsur-unsur pemaaf maupun pembenar.

Menimbang bahwa berdasarkan alat bukti berupa keterangan saksi-saksi, keterangan terdakwa, surat dan petunjuk dan diperkuat dengan barang bukti dapat disimpulkan bahwa terdakwa telah melakukan suatu tindak pidana dan untuk itu terdakwa harus mempertanggung jawabkan perbuatannya. Menimbang, bahwa berdasarkan uraian tersebut diatas maka dengandemikian unsur ini telah terbukti secara sah dan meyakinkan menurut hukum.

Ad.2. Percobaan atau permufakatan jahat untuk melakukan tindak pidana tanpa hak dan melawan hukum memiliki, menyimpan, menguasai, atau menyediakan Narkotika Golongan I bukan tanaman yang beratnya lebih dari 5 (lima) gram.

Menimbang bahwa yang dimaksud dengan percobaan adalah adanya unsurunsur niat, adanya permulaan pelaksanaan, dan tidak selesainya pelaksanaan bukan semata-mata disebabkan karena kehendaknya sendiri;

Menimbang bahwa permufakatan jahat adalah perbuatan dua orangatau lebih yang bersekongkol atau bersepakat untuk melakukan, melaksanakan, membantu, turut serta melakukan, menyuruh, menganjurkan, memfasilitasi, memberi konsultasi, menjadi anggota suatu organisasi kejahatan Narkotika,atau mengorganisasikan suatu tindak pidana Narkotika sebagaimana ketentuanPasal 1 ayat 18 UU Narkotika ${ }^{10}$;

Menimbang, bahwa yang dimaksud dengan "Tanpa Hak" ialah pada diri seseorang (Terdakwa) tidak ada kekuasaan / kewenangan atau sesuatu dimana kewenangan itu baru ada setelah ada ijin/sesuai dengan UndangUndang/Peraturan yang membolehkan untuk itu ;

\footnotetext{
${ }^{10}$ July Esther, Manullang, H., Debora, \& Arismani. (2021). Aspek Hukum Pidana Dampak Penyalahgunaan Narkotika Bagi Remaja. Jurnal Visi Pengabdian Kepada Masyarakat, 2(2), 75-88. https://doi.org/10.51622/pengabdian.v2i2.333
} 
Menimbang, bahwa yang dimaksud dengan melawan hukum menurut Pompe adalah melakukan atau tidak melakukan suatu perbuatan yang melanggar hak orang lain dan bertentangan dengan kewajiban hukum yang melakukan perbuatan tersebut, serta bertentangan dengan kesusilaan dan asas-asas pergaulan di masyarakat (sebagaimana dikutip oleh Lamintang dalam bukunya "Dasar-dasar Hukum Pidana Indonesia) dalam hal ini perbuatan terdakwa bertentangan dengan atau telah melanggar ketentuan dalam Undang-undang No 35 Tahun 2009 tentang Narkotika ; Menimbang bahwa unsur memiliki adalah mempunyai sesuatu baiksecara legal (dengan Ijin) ataupun Illegal (dengan tanpa hak atau melawan hukum)

Menimbang, bahwa unsur menguasai adalah keadaan memegang atau menikmati sesuatu benda dimana seseorang menguasainya dengan baik;

Pada pertimbangan diatas "hakim memperhatikan fakta-fakta hukum" pada umumnya dasar dari suatu pidana adalah BAP (Berita Acara Pemeriksaan) pada tingkat penyidik. Secara nyata berdasarka apa yag dituliskan dala BAP dakwaan pertama pasal 114 ternyata terbukti dipegadilan adapun unsur pembuktian itu diterangkan pada kronologi kasus atau BAP kepolisian yang memuat: "Bahwa terdakwa memperoleh narkotika jenis sabu tersebut dari Oji Kemal (DPO) dan Oji Kemal menyerahkan narkotika jenis sabu kepadaterdakwa adalah untuk dijual kembali dan apabila narkotika jenis sabu itusudah habis terjual maka terdakwa langsung menyetorkan hasil penjualantersebut kepada Oji Kemal dan meminta kembali narkotika jenis sabu yanglain untuk terdakwa jual kembali. Dan dari penjualan narkotika jenis sabuitu terdakwa mendapat upah dari Oji Kemal"

Akan tetapi Hakim berpendapat lain dalam melihat unsur pada dakwaan yang diajukan jaksa. Hakim memilih berdasarkan keyakinannya sehingga memutus untuk membuktikan dakwaan alternatif kedua yang mana pertimbangan pasalnya telah diuraikan penulis diatas. Selain pertimbangan pembuktian pasal sebelum memutus hakim juga memperhatikan keadaaan yang memberatkan dan keadaan yang meringankan yang berisikan sebagai berikut, keadaan yang memberatkan:

1. Bahwa perbuatan terdakwa menghambat program pemerintah dalamm emberantas Penyalahgunaan dan peredaran illegal Narkotika;

2. Bahwa Terdakwa tidak mengakui perbuatannya.

3. Bahwa Terdakwa sudah pernah dihukum.

Bahwa Terdakwa masih berusia muda. Setelah semua pertimbangan yang ada kemudian vando sinaga dinyatakan bersalah kemudian "di pidana penjara selama 6 (enam) tahun dan 6 (enam) bulan ditambah pidana dendasebesar Rp. 800.000.000.- (delapan ratus juta rupiah), dengan ketentuan apabila pidana denda tersebut tidak dibayar oleh terdakwa maka dapatdiganti dengan pidana penjara selama 3 (tiga) bulan; "Sesuai dengan uraian yang memberatkan diatas dinyatakan bahwa terdakwa sudah pernah dihukum, penulis berpendapat kemungkinan besar terdakwa pernah dihukum pada hal yang sama atau dengan kata lain tidak adanya efek jera bagi terdakwa setelah dihukum. Hal ini juga berkaitan dengan P.A.F. Lamintang yang menyatakan bahwa Pada dasarnya terdapat tiga pokok pemikiran tentang tujuan yang ingin dicapai dengan suatu pemidanaan, yaitu :

1. Untuk memperbaiki pribadi dari penjahat itu sendiri;

2. Untuk membuat orang menjadi jera dalam melakukan kejahatan kejahatan, dan 


\section{PATIK : JURNAL HUKUM Vol : 09 No. 1, April 2020, Hal 29 - 39}

3. Untuk membuat penjahat-penjahat tertentu menjadi tidak mampu untuk melakukan kejahatan-kejahatan yang lain, yakni penjahat yang dengan cara cara yang lain sudah tidak dapat diperbaiki lagi.

Dasar pemikiran agar suatu kejahatan dapat dijatuhi hukuman artinya penjatuhan pidana mempunyai tujuan tertentu, misalnya memperbaiki sikap mental atau membuat pelaku tidak berbahaya lagi, dibutuhkan proses pembinaan sikap mental. Dalam hal Narkotika, perlunya ditegakan proses rehabilitas terhadap pengguna Narkotika, agar pengguna bebas dari ketergantungan untuk dapat memperbaiki kehidupanya. Rehabilitasi terhadap pecandu narkotika adalah suatu proses pengobatan yang bertujuan untuk membebaskan pecandu dari ketergantungan dan masa rehabilitasi sendiri dipersamakan dengan masa menjalani hukuman.

Rehabilitasi terhadap pecandu narkotika juga merupakan suatu bentuk perlindungan sosial yang mengintegrasikan pecandu narkotika kedalam tertib sosial agartidak lagi melakukan penyalahgunaan narkotika. Apabila pecandu tidak direhabilitasi, maka besar kemungkinan akan ada tindak kejahatan yang dilakukan di kemudian hari. Pertanggungjawaban pidana terkait penyalahgunaan produk turunan narkotika sangat diperlukan dalam penegakan hukum pidana di Indonesia hal ini dikarenakan produk turunan narkotika memiliki efek yang sangat buruk bagi kesehatan manusia yaitu dapat merusak fisik dan mental. Bahaya dan akibat dari penyalahgunaan narkotika tgersebut dapat bersifat bahaya pribadi bagi sipemakai dan dapat pula berupa bahaya sosial masyarakat atau lingkungan. Produk turunan narkotika masih belum diatur secara spesifik oleh Undang-Undang Nomor 35 Tahun 2009 Tentang Narkotika. Sehingga, pertanggungjawabannya terbentur oleh asas legalitas, "nullum delictum, nulla poena sine praevia lege poenali" Suatu tindak pidana tidak dapat dipertanggungjawabkan dalam hukum pidana apabila tidak terdapat peraturan yang mengaturnya terlebih dahulu. Atau dengan kata lain.

Hal ini juga sesuai dengan aliran Hukum Positif, yang mana mengidentikkan hukum dengan undang-undang, atau dengan kata lain tidak ada hukum diluar undangundang Maka, dalam hal ini dapat menjadi celah hukum bagi pelaku tindak pidana penyalahgunaan produk turunan narkotika. Selanjutnya diperlukan upaya pemerintah dan instansi terkait untuk membentuk pertanggungjawaban pidana bagi pelaku tindak pidana penyalahgunaan produk turunan narkotika serta bagaimana seharusnya undang-undang mengatur mengenai produk turunan narkotika, Sehingga pelaku tindak pidana tidak lepas dari jeratan hukum.

Ketentuan perundang-undangan yang mengatur masalah narkotika telah disusun dan diberlakukan, namun demikian kejahatan yang menyangkut tentang narkotika belum dapat diredakan. Dalam banyak kasus terakhir, banyak bandarbandar dan pengedar yang tertangkap dan mendapat sanksi berat, namun pelaku lain seperti tidak mengacuhkannya bahkan lebih cenderung untuk memperluas daerah operasinya. Salah satunya di bidang regulasi yang ditandai dengan diundangkannya Undang-Undang Nomor 22 Tahun 1997

tentang Narkotika. Seiring dengan perkembangan kejahatan narkotika, undang undang tersebut dianggap sudah tidak lagi memadai, maka kemudian dikeluarkan Undang-Undang Nomor 35 tahun 2009 tentang Narkotika.

\section{Kesimpulan Dan Saran}

Narkotika adalah zat atau obat yang berasal dari tanaman atau bukan tanaman, baik sintetis maupun semisintetis, yang dapat menyebabkan penurunan atau perubahan kesadaran, hilangnya rasa, mengurangi sampai menghilangkan rasa nyeri, dan dapat 
menimbulkan ketergantungan, yang dibedakan ke dalam golongan- golongan sebagaimana terlampir dalam Undang-Undang ini. Sesuai dengan analisi penulis pada putusan Nomor2638/Pid.Sus/2019/PN Medan, menyimpulkan banyaknya keselahan yang dalam bentuk kelaaliann maupun kesengaajaan, dimulai dari jenis dakwaan yang digunakan, yang seharusnya menggunakan dakwaan subsideir akan tetapi jaksa penuntut umum memilih dakwaan alternatif, sesuai dengan fakta hukum yang ada, sangat jelas terbukti pasal 114 pada dakwaan alternatif pertama terbukti sesuai dengan BAP, akan tetapi hakim berpendapat lain sehingga memutuskan untuk memilih dakwaan alternatif kedua. Seharusnya penegak hukum harus sesuai dengan asas "Fiat justitia ruat caelum" artinya "Hendaklah keadilan ditegakkan, walaupun langit akan runtuh". Perlunya ketelitian dalam proses penegakan hukum dari penyidik hinga hakim sehingga menghasilkan suatu prodak hukum yang badil dan dapat diterima semua orang.

Dalam pidana Narkotka kiranya hakim juga harus mempertimbangkan tujuan pemidanaan agak pertimbangan tentang Rehabilitasi di gunakan untuk mencegah agar pelaku tidak melakukan kesalahanya untuk yang kedua kali.

\section{DAFTAR PUSTAKA}

\section{Buku}

Abidin Farid Zainal, 2007, Hukum Pidana 1, Sinar Grafika, Jakarta,,

Dirjosisworo Soedjono.1990. Hukum Narkotika di Indonesia. Bandung .PT. citra Aditya bakti.

Makarro Moh, Taufik, Suhasril,.Zakky H.Moh " tindak Pidana Narkotika" Ghalia Indonesia" Jakarta 2003

Marpaung Leden, Asas-Teori-Praktik Hukum Pidana, Sinar Grafika,. Jakarta, 2005, M. Sholehuddin, Sistem Sanksi dalam Hukum Pidana: Ide Dasar Doble Track System \& Implementasinya, Rajawali Pers, Jakarta, 2004,

Muladi. Lembaga Pidana Bersyarat, P.T. Alumni. Bandung, 2004,

Setiady Tolib, Pokok-Pokok Hukum Penitensier Indonesia, Bandung, Alfabeta, 2010,

Hermawan S. Rachman 1987. Penyalahgunaan Narkotika Oleh Para Remaja. Bandung. Penerbit Eresco.

Hamzah Andi, Asas-Asas Hukum Pidana, Rineka Cipta, Jakarta, 1991,

Huda Choerul, Dari Tiada Pidana Tanpa Kesalahan Menuju Kepada Tiada Pertanggungjawaban Pidana tanpa Kesalahan, Kencana,Jakarta, 2006,

Ira Thania Rasjidi dan H. Lili rasjidi “ Dasar-Dasar Filsafat dan Teori Hukum” PT. Citra Aditya Bakti, cetkan ke-11, Bandung

July Esther, Manullang, H., Debora, \& Arismani. (2021). Aspek Hukum Pidana Dampak

Penyalahgunaan Narkotika Bagi Remaja. Jurnal Visi Pengabdian Kepada Masyarakat, 2(2), 75-88. https://doi.org/10.51622/pengabdian.v2i2.333

Lamintang, 1984, Hukum Penitersier Indonesia. Alumni , Bandung

Poeromo Bambang 1994, "Asaas-asas Hukum Pidana” Ghalia Indonesia terbitan ke-7 Yogyakarta

Prodjodikoro Wirjono, Hukum Acara Pidana di Indonesia, Sumur Bandung, Bandung, 1981

Prakoso Djoko, Surat Dakwaan, Tuntutan Pidana dan Eksaminasi Perkara di Dalam Proses Pidana, Liberty, Yogyakarta, 
Ridwan Zachrie dan Wijayanto, Korupsi Mengorupsi Indonesia, PT Gramedia Pustaka Utama,Jakarta,2009,

Sudarto. Hukum dan Hukum Pidana. Alumni. Bandung, 1997

Supramono, G. 2001. Hukum Narkotika Indonesia.Djambatan, Jakarta.

Soekanto Soerjono, 2002, "Pokok-Pokok Sosilologi Hukum" PT.Raja Grafindo Persada,cetakan ke-12, Jakarta

Waluyo Bambang, "Penelitian Hukum dalam Praktek" Sinar Grafika, cetakan ke-4, Jakarta

\section{Peraturan Perundang-undangan}

Undang -undang No. 39 Tahun 2009 Tentang Narkotika.

Pasal 8 Angka 3 Peraturan Bersama Ketua Mahkamah Agung Republik Indonesia, Menteri Hukum Dan Hak Asasi Manusia Republik Indonesia,Menteri Kesehatan Republik Indonesia,Menteri Sosial Republik Indonesia,Jaksa Agung Republik Indonesia,Kepala Kepolisian Negara Republik Indonesia,Kepala Badan Narkotika Nasional Republik Indonesia Tentang Penanganan Pecandu Narkotika Dan Korban Penyalahgunaan Narkotika Ke Dalam Lembaga Rehabilitasi 